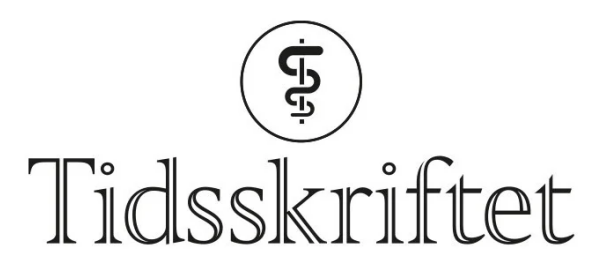

DEN NORSKE LEGEFORENING

\title{
Monoklonalt antistoff som profylakse mot postoperativ venetrombose
}

FRA ANDRE TIDSSKRIFTER

TORBJØRN ØYGARD SKODVIN

Tidsskriftet

\section{En engangsdose med abelacimab, et monoklonalt antistoff mot koagulasjonsfaktor XI, var mer effektivt enn daglige injeksjoner med lavmolekylært heparin.}

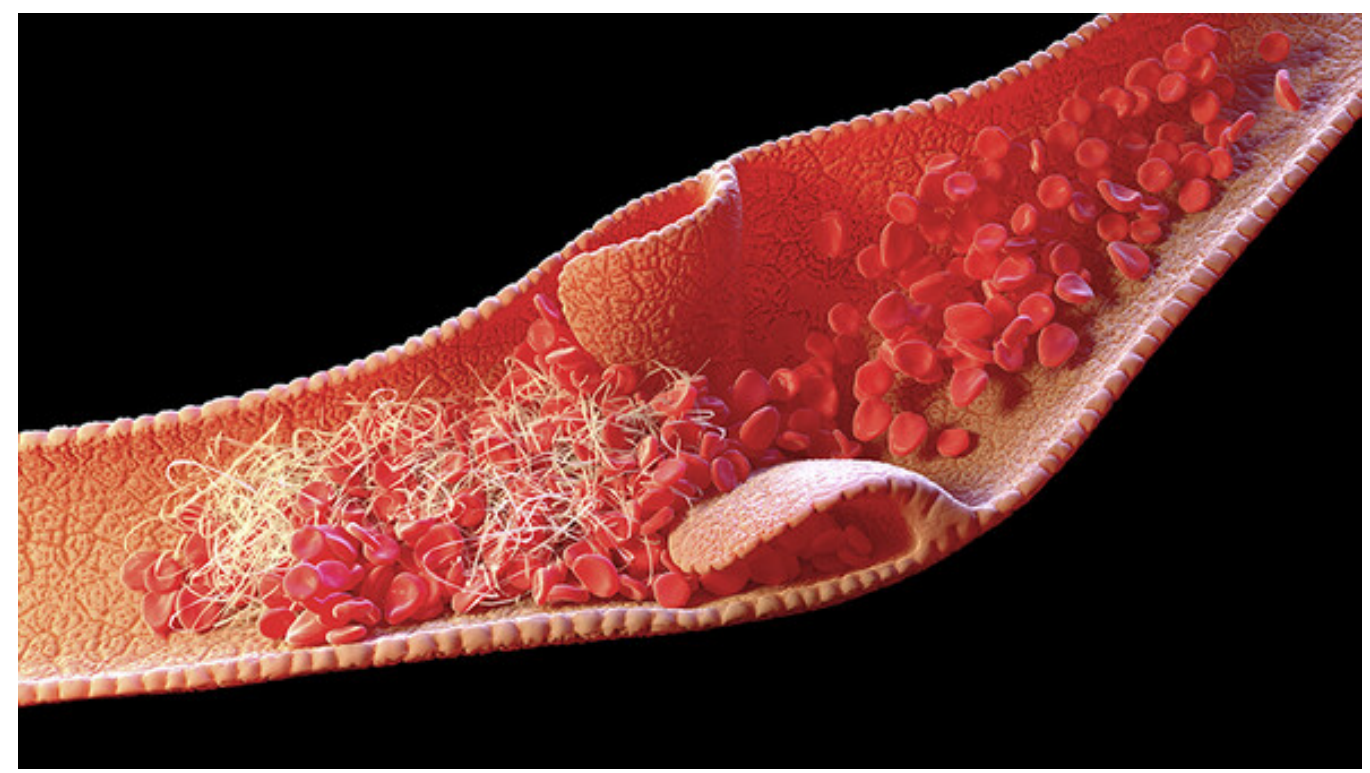

Illustrasjon: Science Photo Library / NTB

Total kneprotesekirurgi er forbundet med høy risiko for venøs tromboembolisme i postoperativ fase. Daglige subkutane injeksjoner med lavmolekylært heparin reduserer risikoen betydelig, men gir risiko for blødning. Personer med medfødt mangel på koagulasjonsfaktor XI har lavere risiko for venøs tromboembolisme uten $ø \mathrm{kt}$ blødningstendens. Et monoklonalt antistoff mot faktor XI, abelacimab, er nå testet ut som tromboseprofylakse etter kneprotesekirurgi.

I en multinasjonal, ublindet studie ble 400 pasienter ved kneprotesekirurgi randomisert til enten én intravenøs injeksjon med abelacimab eller daglige subkutane injeksjoner med enoksaparin (1). Tre ulike doseringer av antistoffet ble testet. Innen 30 dager oppsto 
symptomatisk eller asymptomatisk venøs tromboembolisme hos $4 \%, 5 \%$ og $14 \%$ av pasientene som var behandlet med henholdsvis høy, middels og lav dose abelacimab, mot hele $22 \%$ i enoksaparin-gruppen. Mindre blødninger oppsto hos kun $2 \%$ av pasientene som fikk middels og høy dose.

- Denne studien har spennende resultater og viser et nytt og mulig generelt prinsipp for antikoagulasjonsbehandling. Funnene bør reproduseres i større, dobbeltblinde studier, sier John-Bjarne Hansen, som er professor og leder for Senter for tromboseforskning ved UiT - Norges arktiske universitet og overlege ved Universitetssykehuset Nord-Norge.

- Det blir spennende å se om dette midlet kan erstatte dagens antikoagulasjonsmidler for større pasientgrupper, som i behandling av venøs tromboembolisme og forebygging av hjerneslag ved atrieflimmer, sier Hansen.

\section{LITTERATUR}

1. Verhamme P, Yi BA, Segers A et al. Abelacimab for prevention of venous thromboembolism. N Engl J Med 2021;385: 6o9-17. [PubMed][CrossRef]

Publisert: 25. oktober 2021. Tidsskr Nor Legeforen. DOI: 10.4045/tidsskr.21.0655

(C) Tidsskrift for Den norske legeforening 2023. Lastet ned fra tidsskriftet.no 26. april 2023. 